\author{
A.N. Dyuryagina, A.A. Lutsenko \\ M. Kozybaev North Kazakhstan State University, Petropavlovsk, Kazakhstan \\ (E-mail: l-a.13@mail.ru)
}

\title{
Investigation of the processes of titanium dioxide dispersion in the presence of various surfactants
}

\begin{abstract}
An essential factor affecting the effectiveness of protective and decorative properties of paint and varnish compositions due to the use of surfactants with inhibitory activity in their formulations, as well as the ability to form permanent (cohesive, adhesive), decorative, insulating films based on their selective adsorption, seems to be a promising improvement of the coating performance characteristics. The mechanism of their physico-chemical effects on the interface and the dispersed medium as a whole depends on the nature of the surfactants and the contacting phases, as well as their quantitative ratio. The paper presents the results of experimental studies of the regularities of the processes of titanium dioxide disaggregation in an aqueous dispersion medium in the presence of three types of surfactants. Introduction of three versions of surfactants intensify processes of disaggregation of particles of titanium in an aqueous dispersion medium. The maximum dispersing effect with respect to titanium dioxide is set for sodium polyacrylate solution. The average diameter of the solid-phase particles in comparison with the characteristics of the base composition decreased from 13 to 4 microns, when this modified additive was introduced at the level of $0.25 \mathrm{~g} / \mathrm{L}$.
\end{abstract}

Keywords: paint-and-lacquer materials, dispersion, pigment, titanium dioxide, aggregation, surfactants, disaggregation, suspension, average diameter, fraction, aggregate, modification.

\section{Introduction}

The process of combining a solid component, a pigment with a liquid dispersion medium in the production of paint-and-lacquer coating, is very important, since the technological properties of paints depend on it, as well as many of the operational properties of coatings. An important technological characteristic of paintand-lacquer materials (PLM) determining the structural and mechanical (covering capacity, wetting [1], hardness, strength) properties of their coatings is the degree of disaggregation of pigments and fillers [2].

Surfactants, molecules of which contain polar groups in the hydrocarbon radical that are lyophilic with respect to the polymer dispersion medium (i.e., bifunctional compounds of various types), are used as pigment surface modifiers for polar dispersion media [3]. This applies to all types of paintwork materials containing polymer solutions in organic solvents (or water for water-soluble polymers) as binder, waterdispersible binders. In recent years, polymeric surfactants have been developed and used due to their high affinity for the polymer medium, can be even more effective than their low-molecular analogues. The method of this pigment surface modification for subsequent incorporation into the polymer medium is very simple, accessible and effective due to the diversity of the polar groups present in the modifier molecules and also to the different structure of their hydrocarbon radicals [4]. However, the action of surfactants in paintand-lacquer systems is subject to certain physico-chemical laws that must be observed for their effective application.

Development of aggregation and disaggregation processes depends both on the surface properties of the solid-phase particles themselves and on the quantitative-qualitative composition of the film-forming, solvents and surface-active additives in paint-and-lacquer coating suspensions. In this regard, it is necessary to know the effect of all these components on dispersion processes in order to optimize the composition of the paint-and-lacquer coating. The purpose of this work is to study the effect of various surfactants on the processes of dispersing solid-phase particles.

\section{Experimental}

We established the patterns of development of the titanium dioxide disaggregation processes (grade R-02) in the composition based on polar solvent (water) and surface-active additives are (TEGO:Glide 100 (polyether siloxane copolymer), Dispers $715 \mathrm{~W}$ (sodium polyacrylate solution) and Dispers $750 \mathrm{~W}$ (aqueous copolymer solution).

Surface-active effect of surfactants was established with usage of a computer-optical analyzer [5], which allows determining the fractional composition of suspensions in an automatic mode, as well as the 
geometric dimensions and configuration characteristics of individual dispersions. A calculated index $d$ that characterizes the average particle diameter of pigments in suspensions was used to quantify the degree of disaggregation.

An electronic converter-attachment with a magnification of $\times 35$ equipped with a standard USB port and a software package was used for an adequate transfer of the image observed in the eyepiece of the microscope. The principle of the electronic video eyepiece is analogous to the principle of the photocell function and consists in converting light energy into electrical energy. The system unit of the attachment with smallformat CCD cameras transforms the images fixed in the eyepiece of the microscope into signals acceptable for perception by the Windows XP system in personal computers. Electronic configuration attachments are compatible with traditional microscopes. The CARLZEISS 451422 microscope was used in the system developed by us.

At the first stage, individual image elements were recognized within the software package «Spectrum of differential distribution» using the method of continuous scanning, then they were transferred to the system unit of the computer and stored (documenting). At the second stage, the processing of the video image was performed with obtaining quantitative information about the specific number of particles (per unit area), their geometric parameters (linear dimensions, configuration, and area) and, finally, the general data on fractional composition were obtained in the automatic mode.

The algorithm for data processing includes the following basic operations:

1. Binarization of the previously saved image is the conversion of the image into black and white. In terms of Photoshop, this concept is called «by level $50 \%$ \%, as this selects a threshold, all values below which turn into a background color (white), and above - to the main color (black).

2. Recognition for continuous scanning and sorting of individual dispersions by the number ( $\mathrm{N}$, units), size and fractional composition $(\mathrm{P}, \%)$ by reading their area in pixels $(\mathrm{S}, \mathrm{px})$. Transformation of the calculated particle size index expressed in pixels into metric units (microns).

3. Calculation of the integral and differential characteristics of the particle distribution (by their number, linear parameters and area) and their reflection in the form of diagrams, distribution functions or in tabular form depending on the optimization parameters (in the studies).

4. Derivation of functional dependences (in the form of equations or graphs) of the different integral and differential characteristics of the particle distribution (by number, linear dimensions or area) depending on the above factors. The latter makes it possible to estimate the contribution of each of them to the development of particle aggregation processes in comparative regimes, namely, the theoretical dependence (the additive function obtained with the assumption of the absence of interactions between the particles), and with respect to some basic variant (for example, in the absence of surfactants) [5-7].

The use of metric particle sizes expressed in micrometers is accepted in the daily practice of the production of pigmented paint-and-lacquer materials. In connection with the variety of shapes of pigment particles, for their size, the so-called equivalent diameter of an ideal spherical particle is accepted. The values of $d$ (microns) were calculated from the results of the determination (for a given multiplicity of magnification $\times 350)$ of the total number of particles or their individual associates $\left(N\right.$, pieces) and the total area $\left(S_{p}\right.$, pixel) they occupy on a fixed (in the eyepiece) image in accordance with the equation (1):

$$
D_{\text {med }}=1.129 \cdot k \cdot \frac{S_{p}}{N}
$$

where $S_{p}$ - is an area of all particles, pixel; $N$ - is a total number of particles; 1.129 - is a constant; $k-$ is a conversion factor to metric units (2):

$$
k=\sqrt{\frac{S_{0}}{S_{p_{0}}}} .
$$

For a standard sample with $S_{0}=4 \cdot 10^{4} \mu \mathrm{m}^{2}$ at a given (in the experiments) multiplicity of the increase by $\times 350$, the area $\left(S_{p 0}\right)$ in DPI units is 32.400 ; value $k=1.235 \mu \mathrm{m} / \mathrm{pixel}^{1 / 2}$. The disaggregating effect was additionally established by the content of fractions $(P, \%)$ of the class - (minus) 44.34 microns.

The procedure for the preparation of suspensions with different surfactant contents $\left(0-8 \mathrm{~g} / \mathrm{dm}^{3}\right.$ (for pigment weight) consisted in preliminary dissolution of a certain mass in a solvent. The resulting solutions (hereinafter A) were sent to prepare suspensions, which was carried out at a temperature of $20^{\circ} \mathrm{C}$ in a sealed reactor (volume $-0.2 \mathrm{dm}^{3}$, cover factor - 0.60) equipped with an agitator (impeller agitator, frequency $\left.300 \mathrm{~min}^{-1}\right)$. The quantitative contents of the titanium dioxide pigment (1\% by weight of the suspension) in the system were varied due to the change in mass loading into solutions A. To stabilize the deformation pro- 
cesses, the samples of suspensions analyzed with a pneumodosimeter (drop volume $-0.02 \mathrm{ml}$ ) were placed on a specimen slide, then fixed with a cover slip and kept under static load $\left(10 \mathrm{~g} / \mathrm{cm}^{2}\right)$ and were subjected to microanalysis for 5 minutes.

\section{Results and discussion}

\section{System «solvent-pigment-surfactant»}

Distribution of dispersions of titanium dioxide pigment by size classes in suspensions containing no surfactant is characterized by the diagram shown in Figure 1. Fractions with a size of $+198.30-451.56$ microns predominate in suspensions; the content of fractions of this class -198.30 microns is $52.00 \%$, fine fractions - not more than $25.00 \%$. Specific amount of pigment particles of titanium dioxide in the absence of surfactants was 2,300 microns, and their average size is 13.00 microns.

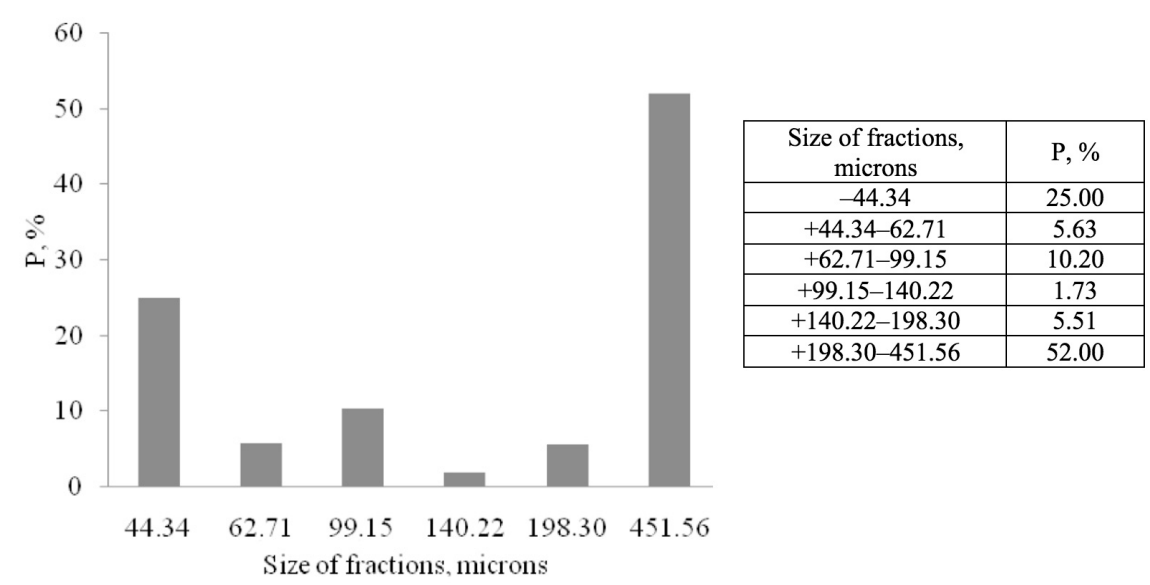

Figure 1. Differential distribution curves by the fineness of the titanium dioxide pigment fractions in a polar solvent

The processes of disaggregation of solid-phase particles of titanium dioxide were intensified significantly with insignificant dosing of surface-active compounds. The positive effect of the surfactants presented is consistent with the patterns of changes in the content of fine fractions $(P)$ and average diameter $(d)$ of the particles (Fig. $2 a, b$ ) in suspensions. The experimental values of the main parameters of the dispersion of solid-phase dispersions in the presence of various types of surfactants are shown in Figure 2.

The maximum disaggregating effect with respect to the titanium dioxide pigment judging by the nature of the change in the average particle size (minima in Figure $2 a$ ) is provided at the Dispers $715 \mathrm{~W}$ surfactant discharge at $0.25-0.50 \mathrm{~g} / \mathrm{dm}^{3}$. The mean statistical particle diameter in the same row decreased by no less than $60.00 \%$ (from 13.00 microns to $4.00-7.00$ microns) in the presence of Glide 100, Dispers $715 \mathrm{~W}$ and Dispers $750 \mathrm{~W}$ in comparison with the characteristics of the basic composition (without surfactant additives).
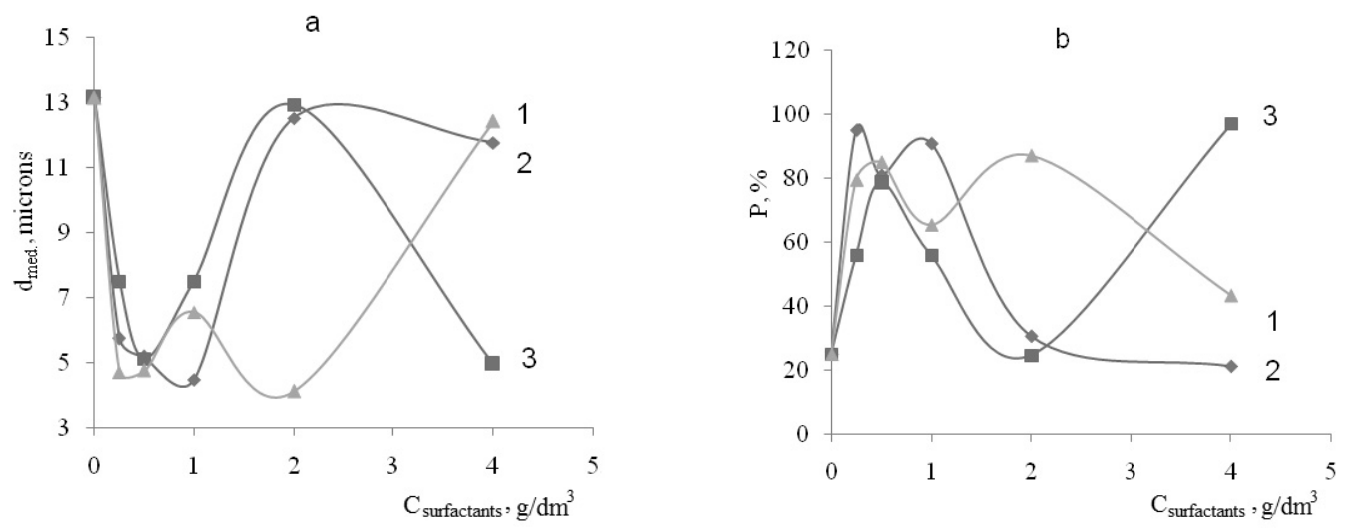

Figure 2. Effect of surfactant coverage rate (1-Dispers 715W, 2-Dispers 750W, 3-Glide 100) on the average diameter $(a)$ and on the content of fine particles of the pigment particles $(b)$ 
The positive contribution of surfactants to the development of disintegration processes is confirmed (Fig. $2 b)$ and the increased content of fine fractions ( $\leq 44.34$ microns) in the case of Dispers $750 \mathrm{~W}$ dispersant, from 25.00 to $73.00 \%$; at the above coverage rate of Glide 100 and Dispers $715 \mathrm{~W}$, the relative content of particles of this class increased by 55.00 and $68.00 \%$. Thus, the dispersion effect in the presence of surfactant is ensured by the destruction of large aggregates of titanium dioxide.

The development of the opposite process is observed with an increase of coverage rate (from 1.00 to $2.50 \mathrm{~g} / \mathrm{dm}^{3}$ ) of Glide 100 and Dispers $750 \mathrm{~W}$ surfactants, an aggregation of solid-phase particles, which corresponds to an increase in the average diameter of the pigment particles from 4.00 to 12.50 and from 7.00 to 13.00 microns, respectively. The aggregation processes were practically not observed in the presence of Dispers $715 \mathrm{~W}$ and when the coverage rates varied from 0.25 to $0.80 \mathrm{~g} / \mathrm{dm}^{3}$, the characteristics of the dispersed pigment composition of titanium dioxide remained practically at the same level $(d \approx 4.00-6.00$ microns; $P \approx 79.00-85.00 \%$ ). Based on this, it follows that the concentration range of the Dispers $715 \mathrm{~W}$ is less restricted than that of Dispers $750 \mathrm{~W}$ and Glide 100. It should also be noted that with an increased concentration of Dispers $750 \mathrm{~W}$ and Dispers $715 \mathrm{~W}\left(4.00 \mathrm{~g} / \mathrm{dm}^{3}\right)$, the average statistical diameter of the pigment particles is increased almost identically to the initial value of the diameter in the absence of surfactants (12.00 microns) and a decrease in the fine fraction by 77.00 and $50.00 \%$, respectively, which indicates the inappropriate use of these surfactants at high concentrations. A slightly different mechanism is observed in the case of the Glide 100 surfactant at the same concentration. The average statistical diameter of solid-state particles decreases up to $62.00 \%$ and, as a consequence, the content of the fine fraction increases in the high-coverage rates region of this modifier $\left(4.00 \mathrm{~g} / \mathrm{dm}^{3}\right)$. This phenomenon suggests the possibility of using this surfactant at elevated system concentrations (above $4.00 \mathrm{~g} / \mathrm{dm}^{3}$ ).

\title{
Conclusions
}

As a result of investigations it can be concluded that introduction of three versions of surfactants intensify the processes of disaggregation of particles of titanium in an aqueous dispersion medium. The maximum dispersing effect with respect to titanium dioxide is set for Dispers $715 \mathrm{~W}$. The average diameter of the solidphase particles in comparison with the characteristics of the base composition decreased from 13.00 to 4.00 microns when this modified additive was introduced at the level of $0.25 \mathrm{~g} / \mathrm{dm}^{3}$.

\section{References}

1 Дюрягина А.Н. Изучение смачивания алюминиевой и стальной подложек полиорганосилоксанами в присутствии азотсодержащих поверхностно-активных веществ / А.Н. Дюрягина, А.В. Демьяненко, В.Ю. Тюканько // Известия Томского политехн. ун-та. Инженеринг георесурсов. - 2017. - Т. 328, № 11. - С. 75-82.

2 Болатбаев К.Н. Модифицирование композитов поверхностно-активными веществами: монография / К.Н. Болатбаев, А.Н. Дюрягина, К.А. Островной. - Петропавловск: Изд-во СКГУ, 2005. -184 с.

3 Ребиндер П.А. Поверхностные явления в дисперсных системах: Сб. науч. тр. / П.А. Ребиндер. — М.: Наука, 1979. T. $1 .-450 \mathrm{c}$.

4 Ребиндер П.А. Физико-химическая механика дисперсных структур / П.А. Ребиндер. - М.: Знание, 1958. - Cep. IV. — № 39, 40. - 64 c.

5 Свидетельство о регистрации интеллектуального продукта 0806 РК 00075. Казахстан. Компьютерно-микрооптический комплекс для анализа порошков и суспензий / К.Н. Болатбаев, Т.Н. Луговицкая, А.А. Тукачев, Р.С. Рустем. Опубл. 01.06.2006.

6 Малышев В.П. Вероятностно-детерминированное планирование эксперимента: монография / В.П. Малышев. - Алма-Ата: Наука КазССР, 1981. - 161 с.

7 Дюрягина А.Н. Особенности изменения поверхностно-активных свойств растворов аминосодержащего ПАВ в уайтспирите / А.Н. Дюрягина, Ю.С. Сидоренко, К.А. Островной, Д.Н. Исмагамбетова, А.А. Кондратов // Хим. журнал Казахстана. - 2013. - Т. 42, № 2. - С. 25-30.

\author{
А.Н. Дюрягина, А.А. Луценко
}

\section{Түрлі беткі белсенді заттардың қатысуымен титан қос тотығының ыдырау процестерін зерттеу}

Лак-бояу жабындарының қорғау және сәндік қасиеттерінің тиімділігіне ықпал ететін елеулі фактор
оларды құрамына енетін дақтар мен толтырғыштардың бытырағыштық дәрежесі болып табылады.
Лак-бояу композицияларын құрамына баяулатқыш белсенділікке, сондай-ақ олардың негізінде саралы 
сіңіруді қалыптастыру қабілетіне ие беткі белсенді заттарды (ББЗ) енгізу есебінен оларды түрлендіру, берік (жұғу, жабысу), сәндік, оқшаулау қабықшалары, жабындардың пайдалану сипаттамаларын жақсартудың перспективалық бағыты болып танылады. Олардың фазалар бөлігінің бетіне және шашыранды ортаға физика-химиялық әсерінің механизмі тұтастай алғанда ББЗ және жанасатын фазалардың табиғатына, сондай-ақ олардың сандық арасалмағына байланысты. Жұмыста титан қос тотығының сулы шашыранды ортада ББЗ үш түрінің қатысуымен агрегатсыздану процестерінің дамуы заңдылықтарының тәжірибелік зерттеу нәтижелері келтірілген. Беткі белсенді заттардың үш түрін енгізу су-дисперсиялық ортада титан диоксидінің бөлшектерін дезагрегациялау үдерісін қарқындатады. Титан диоксидіне қатысты максималды диспергирлеуші әсер натрий полиакрилаты ерітіндісі үшін тағайындалған. Осы түрлендірілген қоспаны 0,25 г/л деңгейінде енгізген кезде базалық құрамның сипаттамаларымен салыстырғанда қатты фазалық бөлшектердің орташа статистикалық диаметрі 13 мкм-ден 4 мкм-ге дейін төмендейді.

Кілт сөздер: лак-бояу жабындары, бытырағыштық, дақ, титан қос тотығы, агрегаттану, беткі-белсенді заттар, агрегатсыздану, суспензия, орта статистикалық диаметр, фракция, агрегат, түрлендіру.

\title{
А.Н. Дюрягина, А.А. Луценко
}

\section{Исследование процессов диспергирования диоксида титана в присутствии различных поверхностно-активных веществ}

\begin{abstract}
Существенным фактором, влияющим на эффективность защитных и декоративных свойств лакокрасочных покрытий, является степень дисперсности входящих в их составы пигментов и наполнителей. Модифицирование лакокрасочных композиций за счет введения в их составы поверхностноактивных веществ (ПАВ), обладающих ингибирующей активностью, а также способностью формировать, на основе их избирательной адсорбции, прочные (когезионные, адгезионные), декоративные, изолирующие пленки, представляется перспективным направлением улучшения эксплуатационных характеристик покрытий. Механизм их физико-химического воздействия на поверхность раздела фаз и дисперсную среду в целом зависит от природы ПАВ и контактирующих фаз, а также их количественных соотношений. В статье приведены результаты экспериментальных исследований закономерностей развития процессов дезагрегации диоксида титана в водной дисперсионной среде в присутствии трех разновидностей ПАВ. Введение трех разновидностей поверхностно-активных веществ интенсифицирует процессы дезагрегации частиц диоксида титана в водной дисперсионной среде. Максимальный диспергирующий эффект по отношению к диоксиду титана установлен для раствора полиакрилата натрия. При введении данной модифицированной добавки на уровне 0,25 г/л среднестатистический диаметр твердофазных частиц по сравнению с характеристиками базового состава уменьшился с 13 до 4 мкм.
\end{abstract}

Ключевые слова: лакокрасочные покрытия, диспергирование, пигмент, диоксид титана, агрегация, поверхностно-активные вещества, дезагрегация, суспензия, среднестатистический диаметр, фракция, агрегат, модификация.

\section{References}

1 Dyuryagina, A.N., Demyanenko, A.V., \& Tyukanko, V.Yu. (2017). Izuchenie smachivaniia aliuminievoi i stalnoi podlozhek poliorhanosiloksanami v prisutstvii azotsoderzhashchikh poverkhnostno-aktivnykh veshchestv [A study of wetting of aluminum and steel substrates by polyorganosiloxanes in nitrogen-containing surfactants]. Izvestiia Tomskoho politekhnicheskoho universiteta. Inzhenerinh heoresursov - Bulletin of the Tomsk Polytechnic University. Engineering of georesources, 328, 11, 75-82 [in Russian].

2 Bolatbaev, K.N., Dyuryagina, A.N., \& Ostrovnoy, K.A. (2005). Modifitsirovanie kompozitov poverkhnostno-aktivnymi veshchestvami [Modification of composites using surfactants]. Petropavlovsk: Izdatelstvo SKGU [in Russian].

3 Rebinder, P.A. (1979). Poverkhnostnye yavleniia v dispersnykh sistemakh [Surface phenomena in disperse systems]. (Vol. 1), Moscow: Nauka [in Russian].

4 Rebinder, P.A. (1958). Fiziko-khimicheskaia mekhanika dispersnykh struktur [Physico-Chemical Mechanics of Disperse Structures]. Moscow: Znanie, 4, 39-40, 64 [in Russian].

5 Bolatbayev, K.N., Lugovitskaya, T.N., Tukachev, A.A., \& Rustem, R.S. (01.06.2006). Certificate of registration of intellectual product 0806 RK 00075 Kazakhstan. Kompiuterno-mikroopticheskii kompleks dlia analiza poroshkov $i$ suspenzii [A computermicro-optical complex for the analysis of powders and suspensions] [in Russian].

6 Malyshev, V.P. (1981). Veroiatnostno-determinirovannoe planirovanie eksperimenta [Probabilistic-deterministic planning of the experiment]. Alma-Ata: Nauka KazSSR [in Russian].

7 Dyuryagina, A.N., Sidorenko, Yu.S., Ostrovnoy, K.A., Ismagambetova, D.N., \& Kondratov, A.A. (2013). Osobennosti izmeneniia poverkhnostno-aktivnykh svoistv rastvorov aminosoderzhashcheho PAV v uait-spirite [Peculiarities of the change in the surface-active properties of amine-containing surfactant solutions in white spirit]. Khimicheskii zhurnal Kazakhstana - Chemical Journal of Kazakhstan, 42, 2, 25-30 [in Russian]. 